\title{
PENGEMBANGAN MODUL ELASTISITAS BERBASIS INKUIRI TERBIMBING UNTUK MENGEMBANGKAN DISIPLIN BELAJAR DAN KREATIVITAS SISWA SMK
}

\author{
Udi Nugroho $^{1}$, Suparmi $^{2}$, dan Nonoh Siti Aminah ${ }^{3}$ \\ ${ }^{1}$ Program Studi Magister Pendidikan Sains FKIP Universitas Sebelas Maret \\ Surakarta, 57126, Indonesia \\ nugroho_udi@rocketmail.com \\ ${ }^{2}$ Program Studi Magister Pendidikan Sains FKIP Universitas Sebelas Maret \\ Surakarta, 57126, Indonesia \\ soeparmi@staff.uns.ac.id \\ ${ }^{3}$ Program Studi Magister Pendidikan Sains FKIP Universitas Sebelas Maret \\ Surakarta, 57126, Indonesia \\ nonoh.nst@gmail.com
}

\begin{abstract}
Abstrak
Pembelajaran Fisika yang diterapkan di SMK Negeri 1 Mondokan belum mengarahkan siswa pada pembelajaran berbasis inkuiri terbimbing dan pembelajaran masih cenderung terpusat pada guru. Penelitian ini bertujuan untuk: (1) mengembangkan modul elastisitas berbasis inkuiri terbimbing untuk meningkatkan disiplin belajar dan kreativitas siswa SMK, (2) mengetahui kelayakan modul elastisitas berbasis inkuiri terbimbing, (3) meningkatkan disiplin belajar dan kreativitas siswa setelah menggunakan modul elastisitas berbasis inkuiri terbimbing. Metode Penelitian ini adalah Reseach and Development. Model pengembangan modul yang digunakan adalah model 4D (four D model) terdiri dari Define, Design, Develop dan Disseminate yang dikemukakan oleh Thiagarajan. Modul dinilai berdasarkan kelayakan materi, media, dan bahasa, serta uji coba (terbatas dan luas) kepada siswa, dan tahap penyebaran pada guru SMK negeri dan swasta. Pengumpulan data menggunakan angket analisis kebutuhan, lembar validasi modul, angket respon uji coba terbatas dan uji coba luas, angket respon disseminate dan lembar observasi disiplin belajar dan kreativitas siswa. Data yang diperoleh dianalisis menggunakan analisis deskriptif, untuk mengetahui kelayakan modul diketahui dari nilai Cut Off, dan untuk mengetahui efektifitas modul untuk meningkatkan sikap disiplin belajar dan kreativitas siswa diketahui dari hasil $\mathrm{N}$-Gain score. Hasil penelitian sebagai berikut: (1) modul elastisitas berbasis inkuiri terbimbing memiliki langkah pembelajaran yang disesuaikan dengan tahapan inkuiri yaitu tahap orientasi, merumuskan masalah, merumuskan hipotesis, mengumpulkan data dengan eksperimen, dan menyimpulkan, (2) modul dikategorikan layak ditinjau dari kelayakan media, materi, dan bahasa, (3) modul elastisitas berbasis inkuiri terbimbing efektif untuk meningkatkan sikap disiplin belajar siswa dengan kategori tinggi berdasarkan hasil $\mathrm{N}$-Gain score 0,61. Modul elastisitas berbasis inkuiri terbimbing juga efektif untuk meningkatkan kreativitas siswa dengan kategori sedang berdasarkan hasil $N$-gain score 0,51 . Hasil belajar siswa juga meningkat berdasarkan hasil $\mathrm{N}$-gain score yaitu 0,59 dengan kategori sedang.
\end{abstract}

Kata Kunci: modul, elastisitas, inkuiri terbimbing, disiplin belajar, kreativitas.

\section{Pendahuluan}

Menurut Undang-Undang no. 20 tahun 2003 tentang Sistem Pendidikan Nasional, Pasal 1 ayat 1 menyatakan bahwa pendidikan adalah usaha sadar dan terencana untuk mewujudkan suasana belajar dan proses pembelajaran agar peserta didik secara aktif mengembangkan potensi dirinya untuk memiliki kekuatan spiritual keagamaan, pengendalian diri, kepribadian, kecerdasan, akhlak mulia, serta keterampilan yang diperlukan dirinya, masyarakat, bangsa dan negara. Menyadari 
pentingnya pendidikan maka pemerintah selalu berupaya meningkatkan kualitas pendidikan di Indonesia.

Upaya pemerintah untuk meningkatkan kualitas pendidikan di Indonesia telah dilakukan dengan berbagai upaya antara lain dengan menyempurnakan sistem kurikulum. Pemerintah juga membuat standar sarana dan prasarana untuk tiap-tiap tingkatan sekolah, misalnya telah ditetapkan dalam Permendiknas no. 40 tahun 2008 bahwa dalam setiap satuan pendidikan setingkat SMK/MAK sekurangkurangnya memiliki laboratorium fisika seluas $64 \mathrm{~m}^{2}$ termasuk ruang penyimpanan seluas $16 \mathrm{~m}^{2}$. Pada ruang praktek fisika juga minimal terdapat 10 macam kit percobaan dan 26 bahan dan alat ukur dasar.

Peningkatan kualitas pendidikan yang terus menerus diharapkan akan menciptakan dunia pendidikan yang selalu dapat mengikuti perkembangan zaman dan perkembangan ilmu pengetahuan dan teknologi. Salah satu faktor penting yang menentukan perkembangan ilmu pengetahuan dan teknologi adalah sains. Sains menurut Putra (2013:41), adalah suatu cara untuk mempelajari aspek-aspek tertentu dari alam secara terorganisir, sistematik, dan melalui metode-metode saintifik yang terbakukan.

Pembelajaran sains bisa dilakukan dengan menggunakan peralatan secara sederhana dan mudah dengan memanfaatkan barang-barang bekas yang disusun menjadi peralatan sederhana. Cara seperti ini akan lebih menyenangkan daripada pembelajaran yang hanya terpusat pada guru. Berdasarkan pendapat di atas maka untuk pembelajaran sains diharapkan menggunakan pendekatan yang memancing keaktifan dan kreativitas siswa. Menurut Hamdani (2011:52), Suasana belajar aktif hanya mungkin terjadi apabila guru turut aktif sebagai fasilitator. Apabila hal tersebut telah terlaksana maka siswa akan aktif dan kreativitasnya juga terpancing.

Upaya pemerintah untuk

meningkatkan kualitas pendidikan nampaknya belum menunjukkan hasil yang optimal. Keterbelakangan sektor pendidikan tercemin dari laporan Human Development Index 2007 (Indeks Pembangunan Manusia 2007), peringkat Indonesia nomor 111 dengan skor 0,734. Indeks Pembangunan Manusia merupakan indikator yang dirancang untuk mengukur kualitas hidup bangsa, akses pendidikan yang layak, harapan hidup dan standar hidup.

Terdapat banyak faktor yang menyebabkan mengapa hasil belajar siswa pada sains pada umumnya dan khususnya adalah pelajaran fisika masih rendah. Salah satu faktornya adalah sejauh mana seorang guru dapat merencanakan proses pendidikan di dalam kelasnya. Proses pendidikan memang harus terencana dan sistematis baik dari metode, media, dan bahan ajar yang digunakan agar hasil yang diperoleh bisa optimal. Menurut Sanjaya (2013:2), Proses pendidikan yang terencana itu diarahkan untuk mewujudkan suasana belajar dan proses pembelajaran, hal ini berarti pendidikan tidak boleh mengesampingkan proses belajar. Pendidikan tidak semata-mata berusaha untuk mencapai hasil belajar, akan tetapi bagaimana memperoleh hasil atau proses belajar yang terjadi pada diri anak.

Suasana belajar dan pembelajaran diarahkan agar peserta didik dapat mengembangkan potensi dirinya, ini berarti proses pendidikan itu harus berorientasi pada siswa (student active learning) dan diarahkan pada dunia nyata, sehingga siswa dapat memahami dari apa yang dipelajari dan menjadi terampil dalam menyelesaikan masalah.

Kekurangtepatan pemilihan metode, media dan bahan pembelajaran juga termasuk salah satu penyebab kurang menariknya sains termasuk fisika bagi siswa. Guru enggan membuat dan mengembangkan bahan ajar yang dapat memancing kreativitas siswa. Kreativitas siswa akan terhenti karena siswa tidak diberi kesempatan untuk mengembangkan ide-idenya yang kreatif itu.

Kreativitas siswa termasuk salah satu faktor internal yang akan 
mempengaruhi keberhasilan siswa dalam belajar. Proses pembelajaran pada hakekatnya adalah untuk mengembangkan kreativitas siswa melalui berbagai interaksi dan pengalaman belajar. Torrance dalam Munandar (2012:27) menyatakan, kreativitas adalah proses merasakan dan mengamati adanya masalah, membuat dugaan tentang kekurangan, menilai, dan menguji dugaan atau hipotesis, kemudian mengubah dan mengujinya lagi, kemudian menyampaikan hasilnya.

Sains dewasa ini sudah berkembang begitu pesat, terutama di bidang fisika. Seorang guru fisika semestinya juga harus menerapkan metode dan media pembelajaran yang variatif dan inovatif yang dapat mendukung kreativitas siswa agar dapat muncul dan berkembang. Hal itu diperkuat dengan pendapat Trianto (2008:163) bahwa, media pembelajaran diharapkan dapat memberikan manfaat, antara lain (1) bahan yang disajikan menjadi lebih jelas maknanya bagi siswa (2) metode pembelajaran lebih bervariasi (3) siswa menjadi lebih aktif melakukan beragam aktivitas (4) pembelajaran lebih menarik (5) mengatasi keterbatasan ruang".

Metode, media, dan bahan pembelajaran yang berbasis inkuiri adalah salah satu alternatif pembelajaran yang inovatif yang bisa digunakan untuk pembelajaran yang sesuai dengan karakteristik pembelajaran fisika dan dapat memancing keaktifan, kedisiplinan belajar dan membangkitkan kreativitas siswa. Suparno (2013:18) menyatakan, oleh karena fisika adalah pengetahuan fisis, maka sangat jelas bahwa untuk mempelajari fisika dan membentuk pengetahuan tentang fisika, diperlukan kontak langsung dengan hal yang ingin diketahui. Itulah sebabnya dalam fisika metode eksperimen dan inkuiri sangat cocok untuk mendalami fisika.

Salah satu metode pembelajaran yang paling mudah dari pendekatan inkuiri dan dapat dikolaborasikan dan dikemas dalam modul adalah dengan metode inkuiri terbimbing. Inkuiri terbimbing dapat dikemas dalam modul dengan harapan siswa dapat belajar mandiri tetapi juga tidak menutup adanya bimbingan dari guru apabila siswa mengalami kesulitan dalam proses belajarnya. Bimbingan guru diharapkan dapat memancing kedisiplinan siswa dalam belajar. Disiplin belajar juga sangat penting dalam pembelajaran karena dapat melatih karakter siswa menjadi lebih baik. Budiman (2010) juga menyatakan bahwa, disiplin diperlukan di manapun, karena dengan disiplin akan tercipta kehidupan yang teratur dan tertata.

Pada penerapan pembelajaran dengan modul berbasis inkuiri terbimbing peserta didik dapat langsung terlibat dalam memperagakan, menunjukkan, mengamati, mencatat segala sesuatu yang terjadi pada kegiatan tersebut dan peserta didik akan terkesan dari apa yang dilihat dan dialaminya sehingga diharapkan peserta didik dapat menarik kesimpulankesimpulan dari proses kegiatan tersebut dengan baik dan diharapkan kreativitas peserta didik akan berkembang. Hal tersebut sesuai dengan Permendiknas no. 22 Tahun 2006 tentang struktur kurikulum SMK/MAK yang menyatakan bahwa pengembangan diri pada SMK/MAK bertujuan untuk mengembangkan kreativitas dan bimbingan karier.

Langkah-langkah pembelajaran dan praktikum dapat dikemas dalam bentuk modul yang berbasis inkuiri terbimbing. Modul dapat membantu siswa untuk memberikan alur pembelajaran sehingga pembelajaran dan penyelidikan pengetahuan (inkuiri) dapat terawasi dan apabila ada kesulitan, guru dapat membimbing siswanya. Menurut Daryanto (2013:9), modul merupakan salah satu bentuk bahan ajar yang dikemas secara utuh dan sistematis, didalamnya memuat seperangkat pengalaman belajar yang terencana dan didesain untuk membantu peserta didik menguasai tujuan belajar yang spesifik.

Materi sifat mekanik bahan atau elastisitas termasuk pada materi SMK program keahlian teknologi dan rekayasa untuk kelas $\mathrm{X}$ semester genap dan nilai 
yang diperoleh siswa kurang memuaskan. Fisika merupakan mata pelajaran adaptif sehingga semestinya dapat menunjang dan mendukung materi produktif (kejuruan). Materi elastisitas merupakan materi yang tidak abstrak karena contoh-contoh aplikasinya konkret dan berhubungan dengan materi kejuruan untuk siswa TKR. Menurut guru yang diwawancarai, nilai siswa untuk materi elastisitas kurang memuaskan karena waktu pembelajaran tidak efektif karena siswa kelas $\mathrm{X}$ pada semester genap harus memperdalam materi produktif untuk mempersiapkan praktek kerja lapangan (PKL). Oleh karena itu modul sangat dibutuhkan untuk mengatasi keterbatasan waktu tersebut. $\mathrm{Hal}$ itu berdasarkan analisis kebutuhan bahwa 93.55\% siswa menyatakan bahwa mereka tidak menggunakan bahan belajar selain yang disediakan sekolah. $75 \%$ guru juga belum memastikan siswa dalam mematuhi langkah kerja pada saat melaksanakan praktikum.

Tujuan dari penelitian ini adalah mengembangkan modul elastisitas berbasis inkuiri terbimbing untuk meningkatkan disiplin belajar dan kreativitas siswa SMK, mengetahui kelayakan modul elastisitas berbasis inkuiri terbimbing untuk meningkatkan disiplin belajar dan kreativitas siswa SMK, dan meningkatkan disiplin belajar dan kreativitas siswa SMK setelah menggunakan modul elastisitas berbasis inkuiri terbimbing

\section{Metode Penelitian}

Metode Penelitian ini merupakan penelitian dan pengembangan (research and development/ $R \& D$ ) yang merupakan hasil adaptasi model 4-D (four-D model) yang dikemukakan oleh Thiagarajan (1974: 5), yaitu Define, Design, Development, dan Desiminate.

Instrumen pengumpulan data dalam penelitian ini menggunakan: (1) angket untuk analisis kebutuhannya, (2) lembar validasi untuk mendapatkan penilaian serta saran terhadap desain produk awal pengembangan, (3) lembar observasi untuk mendapatkan data tentang sikap disiplin belajar dan kreativitas, (4) tes untuk melihat peningkatan hasil belajar siswa pada proses pembelajaran. Tes diberikan dua kali yaitu pretest dan posttest.

Desain modul elastisitas berbasis inkuiri terbimbing meliputi bagian awal, inti dan akhir. Modul bagian awal yaitu cover, pendahuluan yang berisi deskripsi modul, prasyarat dan petunjuk penggunaan. Bagian inti yaitu kegiatan belajar yang berisikan tujuan pembelajaran, siswa diberikan fenomena dalam kehidupan sehari-hari kemudian diminta merumuskan masalah, selanjutnya siswa diminta berhipotesis, melakukan percobaan untuk menyelesaikan masalah dan menyimpulkan hasilnya, terdapat juga rangkuman, contoh soal, dan evaluasi untuk mengukur hasil belajar siswa. Bagian akhir yaitu glosarium, penutup, daftar pustaka.

Tahap validasi produk awal dalam penelitian pengembangan ini melibatkan 2 pakar yang berlatar belakang pendidikan S3 dan 1 pakar berlatar belakang pendidikan S2, 2 orang peer review, dan 2 orang guru fisika. Modul yang sudah divalidasi diujicobakan secara terbatas pada 10 siswa TKR kelas X SMK Negeri 1 Mondokan dilanjutkan dengan ujicoba skala besar dengan jumlah siswa sebanyak 31 siswa setelah melalui tahap revisi produk pembelajaran selanjutnya akan di sebarkan kepada guru SMK negeri dan swasta sebanyak 14 orang.

Instrumen dalam penelitian adalah angket analisis kebutuhan, lembar validasi, lembar respon siswa terhadap modul, dan tes. Data yang dikumpulkan dalam penelitian ini adalah data hasil analisis kebutuhan, hasil lembar validasi, hasil uji coba terbatas dan uji coba luas. Penilaian akhir hasil validasi modul di adaptasi Winnie (2009) dengan Natural Cut Off. Hasil penilaian yang digunakan adalah hasil validasi oleh ahli media, ahli materi, ahli bahasa, guru, dan peer review. Jika skor rata-rata hasil penilaian lebih besar dari skor batas bawah, maka dapat disimpulkan 
bahwa layak untuk digunakan. Adapun kualifikasi validator dapat dilihat pada Tabel. 1.

Tabel 1. Kualifikasi Validator

\begin{tabular}{lllll}
\hline No & Validator & \multicolumn{3}{c}{ Kualifikasi } \\
\hline 1 & Ahli media & $\begin{array}{l}\text { Pendidikan terakhir S3 dan } \\
\text { menguasai media pembelajaran }\end{array}$ \\
\hline 2 & Ahli materi & $\begin{array}{l}\text { Pendidikan terakhir S3 dan } \\
\text { menguasai bidang fisika }\end{array}$ & S2 dan \\
\hline 3 & Ahli bahasa & $\begin{array}{l}\text { Pendidikan terakhir S2 } \\
\text { menguasai bidang kebahasaan }\end{array}$ \\
\hline 4 & Guru fisika & $\begin{array}{l}\text { Pendidikan terakhir S1 dan menjadi } \\
\text { guru fisika SMK }\end{array}$ \\
\hline 5 & $\begin{array}{l}\text { Teman } \\
\text { sejawat }\end{array}$ & $\begin{array}{l}\text { Pendidikan terakhir S1 pendidikan } \\
\text { fisika }\end{array}$ \\
\hline
\end{tabular}

Peningkatan hasil belajar siswa dalam penelitian ini mengacu pada perolehan hasil perhitungan analisis menggunakan gain ternormalisasi menggunakan data prestest dan posttest pada kegiatan pembelajaran. Hasil belajar dikatakan ada peningkatan ketika hasil perhitungan gain menunjukkan minimal kategori sedang (Azwar, 2007:43). Data sikap disiplin belajar dan kreativitas siswa diperoleh dari observasi sebelum dan setelah menggunakan modul, kemudian untuk mengetahui peningkatannya juga dihitung nilai gain ternormalisasi.

\section{Hasil Penelitian dan Pembahasan}

\section{A. Hasil Penelitian}

Penelitian ini menghasilkan produk utama yaitu modul elastisistas berbasis inkuiri terbimbing untuk meningkatkan disiplin belajar dan kreativitas siswa. Model pengembangan berdasarkan tahap 4D (Define, Design, Develop and Diseminate) yang dikemukakan oleh Thiagarajan. Data hasil pengembangannya pada setiap tahap 4-D adalah:

\section{Define}

Tahap ini merupakan tahapan untuk mengidentifikasi masalah-masalah yang ada dalam proses pembelajaran dan menjadi dasar untuk merancang produk berupa modul yang akan dibuat. Pada tahapan ini dilakukan analisis pada guru, siswa, dan materi di SMK Negeri 1 Mondokan. Pengisian angket kebutuhan digunakan untuk menganalisis kebutuhan guru dan siswa pada sekolah tersebut.

Hasil wawancara terhadap guru dalam tahap analisis kebutuhan yang telah dilakukan di SMK Negeri 1 Mondokan menghasilkan data bahwa $93.55 \%$ siswa menyatakan bahwa mereka tidak menggunakan bahan belajar selain yang disediakan sekolah. $75 \%$ guru juga belum memastikan siswa dalam mematuhi langkah kerja pada saat melaksanakan praktikum. Materi elastisitas di pilih karena berhubungan dengan mata pelajaran kejuruan namun siswa masih mengalami kesulitan meskipun materi tersebut konkret dan banyak terdapat contohnya dalam kehidupan sehari-hari.

Berdasarkan hasil analisis materi, angket kebutuhan guru dan siswa maka diperoleh kesimpulan bahwa diperlukan modul elastisitas berbasis inkuiri terbimbing untuk meningkatkan disiplin belajar dan kreativitas siswa.

\section{Design}

Tahap desain merupakan tahap pembuatan silabus, RPP, dan pola keterkaitan kemudian digunakan sebagai acuan dalam pembuatan draft I modul elastisitas berbasis inkuiri terbimbing. Pada tahap desain awal modul yang dikembangkan dilakukan penyusunan modul yang akan menghasilkan draf modul I yang didalamnya mencakup: tujuan yang harus dicapai, petunjuk penggunaan, kegiatan belajar, rangkuman materi, latihan soal, sekilas info, tokoh fisika, materi, dan soal tes.

Draf I modul elastisitas berbasis inkuiri terbimbing terdiri dari empat kegiatan belajar. Kegiatan belajar I dan II tentang sifat keelastisan bahan. Kegiatan belajar III tentang hukum Hooke dan Kegiatan belajar IV tentang susunan pegas. Selain modul, disusun pola keterkaitan, silabus, RPP, kisi-kisi lembar observasi disiplin belajar dan kreativitas serta kisi-kisi tes hasil belajar untuk mendukung proses pembelajaran. 


\section{Development}

\section{a. Hasil Evaluasi Produk}

Data hasil uji produk meliputi data hasil validasi modul dari ahli materi, ahli media, ahli bahasa, guru fisika, dan peer review. Validasi ini meliputi penilaian aspek kelayakan materi, aspek media, aspek kebahasaan yang berupa skor yang dikonversikan dalam lima kategori yaitu sangat baik, baik, cukup, kurang, dan sangat kurang. Dua dosen menilai dari kelayakan materi, dan kelayakan media pada modul, ketua MGMP bahasa Indonesia kabupaten menilai dari kelayakan bahasa dan dua guru fisika dan dua teman sejawat menilai semua aspek tersebut pada modul. Hasil penilaian modul yang dilakukan oleh dosen terdapat pada Tabel 2 .

Tabel 2. Hasil Validasi Produk oleh Validator Ahli

\begin{tabular}{ccccc}
\hline Validasi & Skor & Rerata & $\begin{array}{c}\text { Skor } \\
\text { maks }\end{array}$ & kategori \\
\hline $\begin{array}{c}\text { Ahli } \\
\text { Media }\end{array}$ & 209 & 135 & 220 & $\begin{array}{c}\text { Sangat } \\
\text { Baik }\end{array}$ \\
\hline $\begin{array}{c}\text { Ahli } \\
\text { Materi }\end{array}$ & 43 & 24 & 50 & $\begin{array}{c}\text { Sangat } \\
\text { Baik }\end{array}$ \\
\hline $\begin{array}{c}\text { Ahli } \\
\text { Bahasa }\end{array}$ & 37 & 30 & 40 & $\begin{array}{c}\text { Sangat } \\
\text { Baik }\end{array}$ \\
\hline
\end{tabular}

Pada saat validasi media skor diperoleh dari 11 aspek kelayakan penyajian yaitu: (1) ukuran fisik modul yang terdiri dari 10 poin, (2) tata letak kulit modul yang terdiri dari 18 poin, (3) topografi kulit modul terdiri dari 20 poin, (4) ilustrasi kulit modul terdiri dari 10 poin,

(5) tata letak isi modul terdiri dari 43 poin,

(6) topografi isi modul terdiri dari 40 poin,

(7) ilustrasi isi modul terdiri dari 17 poin,

(8) kelengkapan sajian terdiri dari 12 poin,

(9) penyajian informasi terdiri dari 17 poin, (10) penyajian pembelajaran terdiri dari 18 poin, (11) kemutakhiran materi 4 poin.

Hasil validasi modul pada kelayakan materi meliputi 3 aspek kelayakan isi yaitu: (1) cakupan materi dengan KI dan KD terdiri dari 12 poin, (2) Aspek keakuratan materi terdapat 8 poin, (3) Aspek relevansi terdiri dari 23 poin.

Hasil validitas modul pada kelayakan bahasa meliputi 3 aspek kelayakan penyajian yaitu: (1) kesesuian bahasa yang terdiri dari 5 poin, (2) dialogis dan interaktif yang terdiri dari 9 poin, (3) kesesuaian dengan kaidah bahasa indonesia terdiri dari 23 poin. Hasil perbaikan modul berdasarkan saran dari ahli media, materi dan bahasa disajikan pada Tabel 3 .

\begin{tabular}{|c|c|c|}
\hline No & $\begin{array}{c}\text { Sebelum } \\
\text { Perbaikan }\end{array}$ & $\begin{array}{c}\text { Sesudah } \\
\text { Perbaikan }\end{array}$ \\
\hline 1 & $\begin{array}{l}\text { Modul harus } \\
\text { dilengkapi judul dalam }\end{array}$ & $\begin{array}{l}\text { Modul dilengkapi } \\
\text { dengan judul dalam }\end{array}$ \\
\hline 2 & $\begin{array}{l}\text { Daftar isi dilengkapi } \\
\text { dengan kata halaman } \\
\text { agar lebih jelas }\end{array}$ & $\begin{array}{l}\text { Daftar isi dilengkapi } \\
\text { dengan kata halaman }\end{array}$ \\
\hline 3 & $\begin{array}{l}\text { Daftar isi langsung } \\
\text { memakai font arab } \\
\text { jangan memakai bab } 1 \text {, } \\
\text { bab } 2 \text { dst }\end{array}$ & $\begin{array}{l}\text { Daftar isi diperbaiki } \\
\text { tentang } \\
\text { penomorannya }\end{array}$ \\
\hline 4 & $\begin{array}{l}\text { Pada tabel spasi } 1 \text { dan } \\
\text { diberi judul tabel }\end{array}$ & $\begin{array}{l}\text { Spasi pada tabel } \\
\text { diganti spasi } 1 \text { dan } \\
\text { setiap tabel diberi } \\
\text { judul }\end{array}$ \\
\hline 5 & $\begin{array}{l}\text { Pada langkah kerja } \\
\text { huruf pertama } \\
\text { menggunakan huruf } \\
\text { kapital }\end{array}$ & $\begin{array}{l}\text { Pada langkah kerja } \\
\text { huruf pertama diganti } \\
\text { huruf kapital }\end{array}$ \\
\hline 6 & $\begin{array}{l}\text { Daftar gambar } \\
\text { memakai huruf kapital } \\
\text { pada huruf pertama } \\
\text { Huruf dan background } \\
\text { dibuat kontras }\end{array}$ & $\begin{array}{l}\text { Judul pada daftar } \\
\text { gambar diganti huruf } \\
\text { kapital dan mengganti } \\
\text { background sub judul } \\
\text { dengan warna kontras }\end{array}$ \\
\hline 7 & $\begin{array}{l}\text { Judul utama Font lebih } \\
\text { besar }\end{array}$ & $\begin{array}{l}\text { Font huruf pada judul } \\
\text { diganti lebih besar }\end{array}$ \\
\hline 8 & $\begin{array}{l}\text { Pemakaian kata kalian } \\
\text { dan kata anda pada } \\
\text { siswa dibuat lebih } \\
\text { konsisten }\end{array}$ & $\begin{array}{l}\text { Kata untuk menyebut } \\
\text { siswa diganti dengan } \\
\text { kalian dan konsisten }\end{array}$ \\
\hline 9 & $\begin{array}{l}\text { Kata-kata untuk } \\
\text { memberi Semangat } \\
\text { pada siswa lebih } \\
\text { diperbanyak dan tata } \\
\text { bahasanya diperbaiki }\end{array}$ & $\begin{array}{l}\text { Memperbaiki tata } \\
\text { bahasa pada modul } \\
\text { dan lebih menambah } \\
\text { kalimat yang memberi } \\
\text { motivasi }\end{array}$ \\
\hline 10 & $\begin{array}{l}\text { Penulisan judul pada } \\
\text { gambar dan grafik } \\
\text { lebih konsisten }\end{array}$ & $\begin{array}{l}\text { Mengganti judul } \\
\text { gambar dan grafik } \\
\text { agar lebih konsisten }\end{array}$ \\
\hline 11 & $\begin{array}{l}\text { Pemakaian huruf } \\
\text { kapital lebih } \\
\text { diperhatikan }\end{array}$ & $\begin{array}{l}\text { Memperbaiki tentang } \\
\text { penggunaan huruf } \\
\text { kapital }\end{array}$ \\
\hline 12 & $\begin{array}{l}\text { Tujuan pembelajaran } \\
\text { disesuaikan dengan } \\
\text { indikator capaian } \\
\text { pembelajaran }\end{array}$ & $\begin{array}{l}\text { Menyesuikan tujuan } \\
\text { pembelajaran dengan } \\
\text { indikator } \\
\text { pembelajaran }\end{array}$ \\
\hline 13 & $\begin{array}{l}\text { ada sebagian gambar } \\
\text { yang pecah }\end{array}$ & $\begin{array}{l}\text { Memperbaiki gambar } \\
\text { agar tidak pecah saat } \\
\text { dicetak }\end{array}$ \\
\hline 14 & $\begin{array}{l}\text { Ciri khusus K-13 } \\
\text { adalah tercapainya } \\
\text { KD-1 sampai KD-4, } \\
\text { setidaknya KD-3 dan } \\
\text { KD-4 }\end{array}$ & $\begin{array}{l}\text { Menambah indikator } \\
\text { agar pembelajaran } \\
\text { dapat mencapai KD-4 }\end{array}$ \\
\hline 15 & $\begin{array}{l}\text { Perhatikan penomoran } \\
\text { KD dan indikator }\end{array}$ & $\begin{array}{l}\text { Memperbaiki } \\
\text { penomoran KD }\end{array}$ \\
\hline 16 & $\begin{array}{l}\text { Gunakan kata } \\
\text { operasional dalam } \\
\text { indikator sehingga } \\
\text { dapat diukur }\end{array}$ & $\begin{array}{l}\text { Mengganti indikator } \\
\text { dengan kata-kata yang } \\
\text { operasional }\end{array}$ \\
\hline
\end{tabular}


Modul elastisitas juga divalidasi oleh 2 orang guru fisika. Hasil validasi oleh guru fisika disajikan pada Tabel 4.

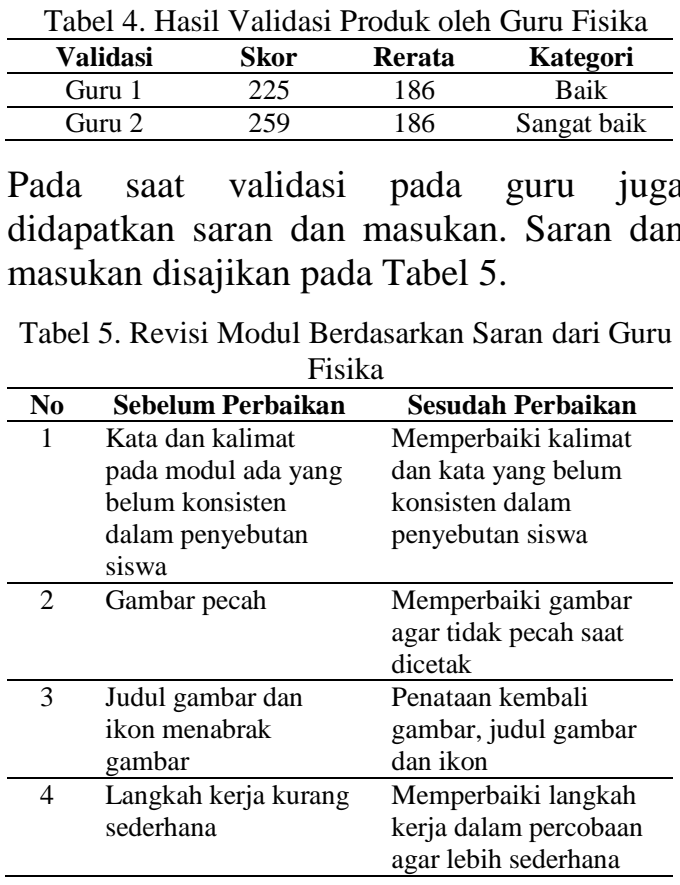

Selain validator ahli dan guru fisika validasi juga dilakukan pada teman sejawat. untuk validasi oleh teman sejawat dapat dilihat pada Tabel 6 .

\begin{tabular}{cccc}
\multicolumn{3}{c}{ Tabel 6. Hasil Validasi Produk oleh Teman Sejawat } \\
\hline Validasi & Skor & Rerata & Kategori \\
\hline $\begin{array}{c}\text { Teman } \\
\text { sejawat 1 }\end{array}$ & 251 & 186 & Sangat baik \\
\hline $\begin{array}{c}\text { Teman } \\
\text { sejawat 2 }\end{array}$ & 244 & 186 & baik
\end{tabular}

Teman sejawat juga memberikan saran dan masukan. Revisi perbaikan berdasarkan saran dan masukan dari teman sejawat disajikan pada Tabel 7.

Tabel 7. Revisi Modul Berdasarkan Saran dari Teman Sejawat

\begin{tabular}{|c|c|c|}
\hline No & Sebelum Perbaikan & Sesudah Perbaikan \\
\hline 1 & $\begin{array}{l}\text { Penulisan rumus } \\
\text { kurang rapi }\end{array}$ & $\begin{array}{l}\text { Penulisan rumus } \\
\text { diperbaiki }\end{array}$ \\
\hline 2 & $\begin{array}{l}\text { Persamaan pada } \\
\text { materi belum } \\
\text { diuraikan }\end{array}$ & $\begin{array}{l}\text { Lebih memperjelas } \\
\text { persamaan-persamaan } \\
\text { pada materi agar lebih } \\
\text { jelas }\end{array}$ \\
\hline 3 & $\begin{array}{l}\text { Simbol kurikulum } \\
2013 \text { pada sampul } \\
\text { terlalu ditepi }\end{array}$ & $\begin{array}{l}\text { Memperbaiki sampul } \\
\text { depan agar simbol } \\
\text { kurikulum } 2013 \text { tidak } \\
\text { terpotong }\end{array}$ \\
\hline
\end{tabular}

\begin{tabular}{cll}
\hline No & Sebelum Perbaikan & Sesudah Perbaikan \\
\hline 4 & $\begin{array}{l}\text { Masih ada kesalahan } \\
\text { penggunaan kata } \\
\text { depan }\end{array}$ & $\begin{array}{l}\text { Memperbaiki } \\
\text { penggunaan kata depan }\end{array}$ \\
\hline 5 & $\begin{array}{l}\text { Hasil cetakan ada } \\
\text { yang bergaris }\end{array}$ & $\begin{array}{l}\text { Memperbaiki hasil } \\
\text { pencetakan dengan } \\
\text { menggunakan kualitas } \\
\text { tinggi }\end{array}$ \\
\hline
\end{tabular}

Kualitas modul berbasis inkuiri terbimbing pada materi elastisitas dilihat dari segi komponen kelayakan media, kelayakan bahasa, kelayakan materi yang masing-masing mempunyai indikator tersendiri. Rangkuman hasil validasi ahli, guru dan teman sejawat modul elastisitas berbasis inkuiri terbimbing dapat dilihat pada Tabel 8.

Hasil penilaian yang digunakan adalah hasil validasi oleh ahli media, ahli materi, ahli bahasa, guru, dan teman sejawat. Jika skor rata-rata hasil penilaian lebih dari skor batas bawah, maka dapat disimpulkan bahwa layak untuk digunakan, digunakan metode cut off score (skor batas bawah) (Winnie,2009). Hasil yang diperoleh pada penelitian adalah nilai rata-rata>nilai cut off sehingga dapat dikatakan bahwa modul masuk dalam kategori layak. Hasil perhitungan nilai cut off disajikan pada Tabel. 8.

\section{b. Revisi I}

Setelah validasi dilakukan, draf I kemudian direvisi berdasarkan saran dan masukan dari para validator dan menghasilkan draf II. Hasil validasi terhadap draf I dan saran yang diberikan oleh masing-masing validator serta revisi tahap I yang diperoleh dari 2 orang dosen fisika, 1 orang ketua MGMP bahasa indonesia, 2 orang guru fisika SMK dan 2 teman sejawat. Draf II selanjutnya diujicobakan terbatas di SMK Negeri 1 Mondokan kelas X TKR 4 yang berjumlah 10 siswa.

Tabel 8. Hasil Validasi oleh Validator

\begin{tabular}{cccc}
\hline No & Validator & $\begin{array}{c}\text { Prosentase } \\
\%\end{array}$ & Kategori \\
\hline 1 & guru & 84 & Sangat baik \\
\hline 2 & guru & 73 & baik \\
\hline 3 & $\begin{array}{c}\text { Teman } \\
\text { sejawat 1 }\end{array}$ & 81 & Sangat baik \\
\hline 4 & $\begin{array}{c}\text { Teman } \\
\text { sejawat 2 } \\
\text { Media }\end{array}$ & 79 & Baik \\
\hline 5 & 91 & Sangat baik \\
\hline
\end{tabular}




\begin{tabular}{cccc}
\hline No & Validator & $\begin{array}{c}\text { Prosentase } \\
\mathbf{\%}\end{array}$ & Kategori \\
\hline 6 & Materi & 84 & Sangat baik \\
\hline 7 & Bahasa & 93 & Sangat baik \\
\hline & Nilai max & $\mathbf{9 3}$ & \\
& Nilai min & $\mathbf{7 3}$ & \\
& Rata-rata & $\mathbf{8 4}$ & \\
Cut off & $\mathbf{8 3}$ & \\
& keterangan & Layak & \\
\hline
\end{tabular}

\section{c. Uji Coba Terbatas}

Uji coba terbatas dilakukan pada siswa kelas $\mathrm{X}$ TKR 4 SMK Negeri 1 Mondokan, Sragen untuk melihat keterbacaan dan mengetahui masukan siswa pada modul elastisitas berbasis inkuiri terbimbing dengan cara mengisi angket respon. Hasil perbaikan modul berdasarkan saran siswa pada uji coba terbatas ditunjukkan pada Tabel 9.

Tabel 9. merupakan hasil respon siswa terhadap modul elastisitas berbasis inkuiri terbimbing pada uji coba terbatas. Rata-rata nilai yang diperoleh adalah 243,8 dengan kategori baik. Saran dan hasil dari uji coba terbatas disajikan pada Tabel 10.

Tabel 9. Hasil Respon Siswa pada Uji Coba Terbatas

\begin{tabular}{ccc}
\hline No & Skor & Kategori \\
\hline 1 & 235 & Baik \\
\hline 2 & 247 & Baik \\
\hline 3 & 239 & Baik \\
\hline 4 & 243 & Baik \\
\hline 5 & 260 & Sangat Baik \\
\hline 6 & 244 & Baik \\
\hline 7 & 238 & Baik \\
\hline 8 & 260 & Sangat Baik \\
\hline 9 & 240 & Baik \\
\hline 10 & 241 & Baik \\
\hline
\end{tabular}

\section{d. Revisi II}

Setelah diujicobakan terbatas modul diperbaiki berdasarkan saran dan masukan dari siswa.

Tabel 10. Revisi pada Uji Coba Terbatas

\begin{tabular}{|c|c|c|}
\hline No & Sebelum Perbaikan & Sesudah Perbaikan \\
\hline 1 & $\begin{array}{l}\text { Kalimat pada langkah } \\
\text { kerja membingungkan }\end{array}$ & $\begin{array}{l}\text { Lebih } \\
\text { menyederhanakan } \\
\text { kalimat pada langkah } \\
\text { kerja }\end{array}$ \\
\hline 2 & Tabel data terlalu kecil & $\begin{array}{l}\text { Menyesuiakan tabel } \\
\text { data agar lebih lebar }\end{array}$ \\
\hline 3 & $\begin{array}{l}\text { Tahapan pembelajaran } \\
\text { masih } \\
\text { membingungkan }\end{array}$ & $\begin{array}{l}\text { Memberikan } \\
\text { pengertian dan } \\
\text { pembimbingan agar } \\
\text { siswa tidak kesulitan } \\
\text { dalam melaksanakan } \\
\text { tahapan inkuiri }\end{array}$ \\
\hline
\end{tabular}

Siswa juga menyarankan sebelum pembelajaran harus diberi tahu dahulu, secara keseluruhan modul mendapatkan respon sangat baik, sehingga dapat dinyatakan bahwa modul elastisitas berbasis inkuiri terbimbing yang dikembangkan layak untuk digunakan. Selanjutnya setelah melalui uji coba terbatas melalui revisi didapatkan draf III yang siap untuk dilakukan uji coba di kelas. Setelah direvisi ke II, disusun menjadi draf modul III yang akan diimplementasikan di kelas X TKR 4.

\section{e. Uji Coba Besar}

Modul dari hasil draf III diujicobakan dalam kelas yang lebih besar yaitu siswa X TKR 4 SMK Negeri 1 Mondokan (kelas pengujian produk). Adapun pelaksanaannya pada bulan Mei 2016. Hal ini bertujuan untuk mengetahui peningkatan sikap disiplin belajar dan kreativitas siswa. Uji coba di kelas dilakukan dengan terlebih dahulu diberikan pretest pada kelas pengujian produk untuk mengetahui gambaran kemampuan awal siswa pada materi elastisitas serta disiplin belajar dan kreativitas siswa sebelum dilakukan pembelajaran, dan setelah pembelajaran selesai dilakukan posttest. Pembelajaran dilakukan dengan menerapkan modul untuk kelas pengujian produk. Guru sebagai fasilitator dalam pembelajaran menggunakan modul elastisitas berbasis inkuiri terbimbing di dalam kelas pengujian produk. Pembelajaran dengan menggunakan modul dilaksanakan sebanyak 3 kali pertemuan dan setiap pertemuan menggunakan alokasi waktu 2 jam pelajaran atau 90 menit. Setelah seluruh proses pembelajaran menggunakan modul tersebut, siswa diminta untuk mengisi angket tanggapan terhadap modul pembelajaran.

\section{f. Analisis hasil}

1) Hasil belajar, Disiplin belajar dan Kreativitas

Sebelum modul elastisitas berbasis inkuiri terbimbing digunakan dalam pembelajaran, instrumen untuk pretest dan posttest yang berupa soal diujicobakan terlebih dahulu pada 34 siswa di SMK 
Negeri 1 Mondokan kelas XII TKJ 3 dengan tujuan untuk mengetahui reliabilitas, analisis butir instrumen daya beda, validitas dan tingkat kesukaran pada soal pretest dan posttest. Setelah diujicobakan dan dianalisis maka soal dinyatakan siap untuk digunakan dalam uji coba besar pada siswa SMK N 1 Mondokan kelas X TKR 4. Sebelum modul dibagikan ke 31 siswa pada kelas $\mathrm{X}$ TKR 4 siswa diberikan pretest terlebih dahulu untuk mengetahui kemampuan awal tentang elastisitas. Modul elastisitas ini diberikan sebagai modul inti dalam pelaksanaan pembelajaran. Setelah materi pada modul selesai, siswa diberikan posttest.

Pengunaan modul dilakukan untuk melihat peningkatan hasil belajar, sikap disiplin belajar dan kreativitas siswa antara sebelum dan sesudah diberikan modul elastisitas berbasis inkuiri terbimbing. Kelas yang digunakan dalam penelitian ini satu kelas yaitu X TKR 4. Sebelum menganalisis hasil pretest dan posttest untuk hasil belajar, sikap disiplin belajar dan kreativitas, data pretest siswa dianalisis normalitasnya terlebih dahulu secara sederhana. Hasil pretest dianalisis dengan menggunakan microsoft excel dan diperoleh nilai mean 40,32, median 40,00 dan modus 40,00 dengan mendapatkan nilai mean, median dan modus yang hampir sama maka dapat disimpulkan bahwa data pretest siswa adalah terdistribusi normal.

Tabel 11. merupakan deskripsi hasil belajar siswa sebelum dan sesudah menggunakan modul elastisitas berbasis inkuiri terbimbing. Pada tabel tersebut dapat diketahui bahwa modul elastisitas berbasis inkuiri terbimbing dapat meningkatkan hasil belajar siswa dengan kategori sedang.

Tabel 11. Data Hasil Belajar Siswa

\begin{tabular}{ccccc}
\hline Tes & $\begin{array}{c}\text { jmlh } \\
\text { siswa }\end{array}$ & Mean & $\begin{array}{c}\text { Nilai } \\
\text { min }\end{array}$ & $\begin{array}{c}\text { Nilai } \\
\text { maks }\end{array}$ \\
\hline Pretest & 31 & 40,52 & 24 & 60 \\
Posttest & 31 & 75,61 & 68 & 88 \\
\hline Gain & & & 0,59 & \\
\hline
\end{tabular}

Tabel 12. merupakan deskripsi sikap disiplin belajar siswa sebelum dan setelah menggunakan modul elastisitas berbasis inkuiri terbimbing. Pada tabel tersebut dapat diketahui bahwa modul elastisitas berbasis inkuiri terbimbing dapat meningkatkan sikap disiplin belajar siswa dengan kategori tinggi.

Tabel 12. Data Disiplin Belajar Siswa

\begin{tabular}{ccccc}
\hline Tes & $\begin{array}{c}\text { Jmlh } \\
\text { siswa }\end{array}$ & Mean & $\begin{array}{c}\text { Nilai } \\
\text { min }\end{array}$ & $\begin{array}{c}\text { Nilai } \\
\text { maks }\end{array}$ \\
\hline awal & 31 & 41,39 & 28 & 70 \\
\hline akhir & 31 & 61,68 & 53 & 70 \\
\hline Gain & & & 0,61 & \\
\hline
\end{tabular}

Tabel 13. merupakan deskripsi kretivitas siswa sebelum dan setelah menggunakan modul elastisitas berbasis inkuiri terbimbing. Pada tabel tersebut dapat diketahui bahwa modul elastisitas berbasis inkuiri terbimbing dapat meningkatkan kreativitas siswa dengan kategori sedang.

Tabel 13. Data Kreativitas Siswa

\begin{tabular}{ccccc}
\hline Tes & $\begin{array}{c}\text { Jmlh } \\
\text { siswa }\end{array}$ & Mean & $\begin{array}{c}\text { Nilai } \\
\text { min }\end{array}$ & $\begin{array}{c}\text { Nilai } \\
\text { maks }\end{array}$ \\
\hline awal & 31 & 43,45 & 28 & 55 \\
akhir & 31 & 66,65 & 55 & 79 \\
\hline Gain & & & 0,51 & \\
\hline
\end{tabular}

\section{2) Keefektifan Modul dalam Pembelajaran}

Analisis untuk mengetahui keefektifan dalam pembelajaran menggunakan gain score ternormalisasi (Meltzer, 2002:1260) untuk pretest dan posttest kelas pengujian produk. Berdasarkan perhitungan gain score untuk kelas pengujian produk, termasuk kategori tinggi untuk meningkatkan disiplin belajar dan termasuk kategori sedang untuk meningkatkan hasil belajar dan kreativitas. 


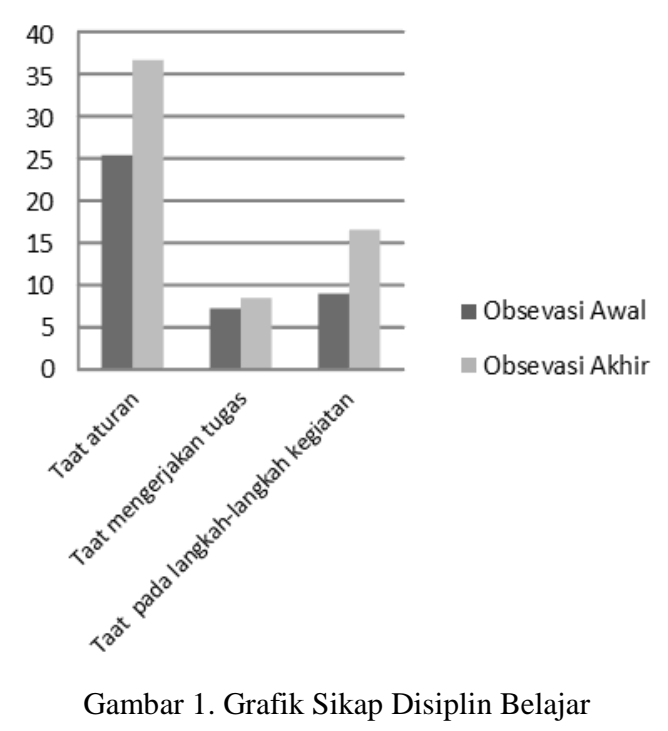

Berdasarkan Gambar 1. disajikan peningkatan dari setiap indikator sikap disiplin belajar sebelum siswa menggunakan modul dan setelah menggunakan modul. Peningkatan yang paling tinggi terlihat pada indikator taat aturan pada saat pembelajaran fisika sedangkan peningkatan yang paling rendah terjadi pada indikator taat mengerjakan tugas.

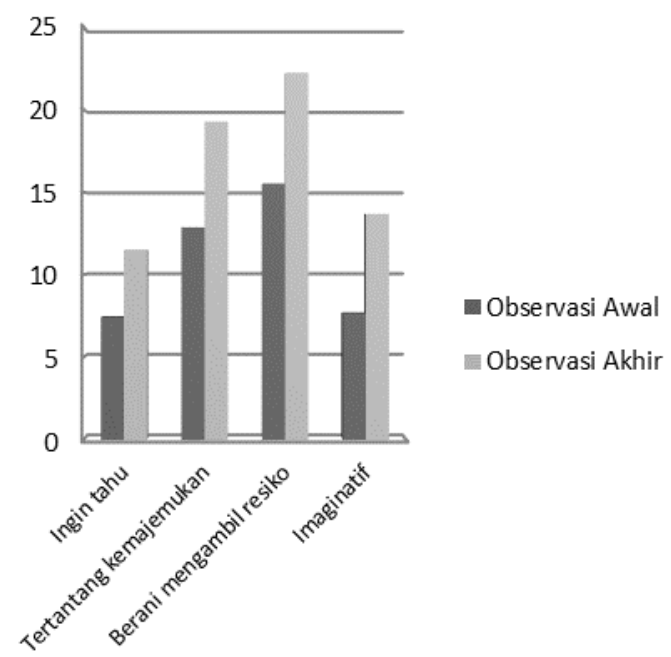

Gambar 2. Grafik Kreativitas Siswa

Pada Gambar 2. disajikan peningkatan dari setiap indikator keterampilan kreativitas sebelum siswa menggunakan modul dan setelah menggunakan modul. Peningkatan paling tinggi terlihat pada indikator berani mengambil resiko sedangkan peningkatan yang paling rendah terjadi pada indikator ingin tahu.

\section{B. Pembahasan}

Pengembangan modul elastisitas berbasis inkuiri terbimbing menggunakan model desain oleh Thiagarajan. Proses terlaksana mulai dengan 4D yaitu (Define, Design, Development, Disseminate).

\section{Define}

Tahapan ini dilakukan penyebaran angket kebutuhan kepada siswa dan guru mengenai pembelajaran fisika di sekolah yang akan dijadikan tempat penelitian. Angket kebutuhan guru diberikan kepada 4 orang guru SMK Negeri 1 Mondokan kabupaten Sragen, Sedangkan angket pengungkap kebutuhan siswa diberikan kepada 31 siswa di sekolah yang sama. Pertanyaan angket kebutuhan siswa terdiri dari 18 pertanyaan. Hasil dari angket pengungkap kebutuhan siswa adalah siswa membutuhkan bahan ajar cetak yang sesuai dengan kurikulum 2013. Siswa belum menggunakan model pembelajaran berbasis saintifik maupun inkuiri dalam pembelajaran. Siswa belum diarahkan pada sikap disiplin belajar dan kreatif. Untuk mencapai sikap disiplin belajar dan siswa yang kreativitasnya tinggi maka pembelajaran seharusnya terpusat pada siswa dan siswa terlibat langsung dalam menemukan pengetahuannya sendiri. Hal tersebut sesuai dengan pendapat Suparno (2013:18) yang menyatakan bahwa, fisika adalah pengetahuan fisis, maka sangat jelas bahwa untuk mempelajari fisika dan membentuk pengetahuan tentang fisika, diperlukan kontak langsung dengan hal yang ingin diketahui. Itulah sebabnya dalam fisika metode eksperimen dan inkuiri sangat cocok untuk mendalami fisika.

Siswa membutuhkan bahan ajar dengan materi yang lengkap. Siswa setuju bila dikembangkan bahan ajar modul pembelajaran berbasis inkuiri terbimbing untuk meningkatkan disiplin belajar dan kreativitas siswa. Materi fisika yang akan dikembangkan adalah materi elastisitas dimana pada silabus disebutkan pada 
kompetensi dasar (KD) 3. 12, 3. 14 dan 4. 9. Pengembangan modul fisika ini mengangkat materi elastisitas, dengan alasan banyaknya aplikasi dalam kehidupan sehari-hari yang dekat dengan siswa pada materi ini serta siswa TKR sangat berhubungan erat dengan materi ini dalam mata pelajaran produktif. Sehingga diharapkan akan lebih memudahkan siswa dalam mempelajari modul dan materi yang akan disajikan.

\section{Design}

Draf awal modul disusun berdasarkan analisis kebutuhan dan tujuan penyusunan modul dengan memperhatikan prinsip-prinsip belajar. Prinsip-prinsip belajar yang menjadi acuan dalam penelitian dan pengembangan ini adalah: 1) motivasi; 2) keaktifan siswa; 3) adanya sarana yang dapat mengembangkan siswa untuk bereksplorasi; 4) penyajian materi secara sederhana; 5) pengulangan; dan 6) sarana belajar yang mendukung. Menurut Hamdani (2011) bahwa belajar terjadi ketika ada interaksi antara individu dan lingkungan, dapat juga berupa modul untuk memotivasi siswa. Dengan demikian buku/modul yang disusun harus memperhatikan karakter siswa sehingga siswa lebih termotivasi untuk belajar. Hal ini dilakukan dengan cara melengkapi modul dengan gambar dan ilustrasi, sehingga menambah daya tarik modul. Hal ini sesuai dengan pendapat Purwanto (2007:137) bahwa fungsi gambar dalam penyusunan modul diantaranya adalah menambah daya tarik dan memotivasi pembaca serta mempermudah memahami pesan atau informasi.

Berdasarkan hal ini, maka gambar dan ilustrasi selain dapat menambah daya tarik pembaca, juga dapat mempermudah memahami materi. Materi disajikan dengan langkah-langkah inkuiri, sehingga pada akhirnya ditemukan keterkaitan antara konsep yang satu dengan yang lainnya terutama yang berkaitan dalam kehidupan sehari-hari.

Tahap-tahap dalam inkuiri terbimbing diberi gambar (ikon) tertentu.
Pemberian gambar ikon setiap sintaks inkuiri, dalam penyusunan modul, bertujuan agar tampilan modul lebih menarik. Apabila tampilan modul menarik maka siswa akan termotivasi untuk menggunakan modul sehingga akan membantu siswa dalam belajar. Dalam menggunakan modul dapat digunakan secara mandiri atau dengan bimbingan dari guru karena dalam modul telah disusun secara sistematis dengan tahapan-tahapan yang jelas. Hal tersebut sesuai dengan pernyataan daryanto (2013:9) bahwa modul merupakan salah satu bentuk bahan ajar yang dikemas secara utuh dan sistematis, didalamnya memuat seperangkat pengalaman belajar yang terencana dan didesain untuk membantu peserta didik menguasai tujuan belajar yang spesifik.

\section{Development}

Depdiknas (2004) menyatakan bahwa modul adalah salah satu bahan ajar dengan tujuan siswa dapat belajar secara mandiri atau dengan bimbingan seminimal mungkin dari pendidik. Modul berisikan tentang materi, kegiatan yang dilakukan siswa, dan lembar evaluasi.

Untuk mengetahui kelayakan pengunaan modul maka dilakukan validasi. Menurut Daryanto (2013:23) validasi dilakukan dengan cara meminta bantuan ahli yang menguasai kompetensi yang dipelajari. Draft modul yang telah disusun kemudian dikonsultasikan kepada dosen ahli (pembimbing). Validasi modul yang dilakukan meliputi validasi ahli materi, ahli media, ahli bahasa, teman sejawat dan guru fisika. kualifikasi dari kelima validasi tersebut dapat dilihat pada Tabel 1.

Pada saat validasi modul validator materi memberikan saran agar memperhatikan indikator pembelajaran. Hal tersebut sesuai dengan pernyataan Depdiknas (2008), dalam penyusunan materi harus memperhatikan kedalaman dan keluasan cakupan materi. Beberapa validator juga menyarankan untuk lebih memperhatikan tata cara penulisan yang baik sesuai dengan Ejaan Yang Disempurnakan (EYD). Menurut 
Depdiknas (2008:12) bahan ajar yang layak digunakan dengan kriteria baik apabila bahan ajar ditulis dengan menggunakan bahasa yang baik dan mudah dipahami, disajikan secara menarik dilengkapi dengan gambar dan keterangan-keterangannya, isi buku juga menggambarkan sesuatu berdasarkan dengan ide penulisnya.

Pada bagian gambar, grafik, dan tampilan juga terdapat beberapa saran agar lebih diperbaiki. Saran dan masukan tersebut sesuai dengan pendapat Sungkono (2003:10) contoh adalah benda, ilustrasi, angka, gambar, dan lain-lain yang mendukung konsep yang disajikan. Pendapat yang sama juga disampaikan Prastowo (2012) yang menyatakan bahwa gambar-gambar dapat mendukung dan memperjelas isi materi sehingga menimbulkan daya tarik. Dari saran dan masukan para validator dijadikan dasar untuk melakukan perbaikan modul.

Berdasarkan hasil validasi pada Tabel 8. dinyatakan bahwa modul layak digunakan. Setelah modul dinyatakan layak digunakan kemudian dilakukan tahap uji terbatas. Uji terbatas ini bertujuan untuk mengetahui keterbacaan modul pada siswa. Keterbacaan modul dilakukan pada 10 siswa kelas $\mathrm{X}$ TKR. Instrumen yang digunakan adalah LKS dan angket keterbacaan modul. Siswa kemudian diberikan modul dan mengerjakan LKS yang digunakan untuk mengisi kegiatan yang ada dalam modul. Ada 4 kegiatan belajar siswa yang terdiri dari percobaan sederhana. Tiap 7 sampai 8 siswa mengerjakan 4 kegiatan yang telah disediakan. Pada saat uji terbatas siswa mengalami beberapa kendala yang kemudian dijadikan saran/masukan untuk perbaikan modul. Selain itu pada uji terbatas siswa diminta untuk membaca modul secara keseluruhan kemudian memberikan penilaian melalui angket. Dari 10 siswa menunjukkan beberapa komentar positif.

Tahap selanjutnya uji luas yang dilakukan setelah melakukan perbaikan pada modul dari tahap sebelumnya. Uji luas dilakukan pada 31 siswa kelas X TKR 4. Hasil dari uji luas sebagai berikut.

\section{a. Data Hasil Belajar, Sikap Disiplin Belajar dan Kreativitas Siswa}

Kelas yang dijadikan kelas ujicoba luas adalah kelas X TKR 4 siswa di SMK Negeri 1 Mondokan. Siswa diberikan soal pretest terlebih dahulu, sebelum diberikan modul berbasis inkuiri terbimbing pada materi elastisitas. Setelah dilakukan pretest, siswa pada kelas X TKR 4 diberikan pembelajaran menggunakan modul. Pertemuan pertama dalam pembelajaran menggunakan modul berbasis inkuiri terbimbing pada materi elastisitas sesuai dengan RPP yang telah disusun sebelumnya. Setelah guru menyampaikan tujuan pembelajaran, motivasi dan apersersepsi, guru juga menjelaskan penggunaan modul dan model pembelajaran yang akan dilaksanakan. Setelah itu guru membagi siswa dalam 5 kelompok. Satu kelompok terdiri dari 6 sampai 7 siswa.

Siswa merumuskan masalah dengan membaca fenomena yang disajikan didalam modul dan menganalisis sehingga mucul masalah yang jelas. Setelah masalah yang menjadi prioritas ditemukan, maka siswa menuliskannya kedalam modul. Siswa juga menentukan jawaban sementara dari masalah yang akan diselesaikan. Pada pertemuan pertama ini siswa masih merasa bingung dalam menentukan dugaan sementara, akan tetapi dengan bimbingan guru dan siswa bekerja secara kelompok siswa berdiskusi dengan kelompoknya dan mampu menuliskan hipotesis dari masalah yang akan diselesaikan. Kemudian siswa menuliskannya di dalam modul. Pada pertemuan pertama sampai ketiga dilakukan 4 kegiatan belajar yang terdiri dari 4 percobaan sederhana yang terdapat didalam modul pembelajaran. Pada saat pertemuan pertama pengamatan tentang sikap disiplin belajar dan kreativitas juga dilaksanakan. Sedangkan pengematan berikutnya dilaksanakan pada pertemuan ketiga atau pertemuan terakhir sebelum posttest. Setelah pembelajaran selesai, dilakukan posttest untuk mengetahui hasil belajar 
siswa setelah dilaksanakan pembelajaran menggunakan modul berbasis inkuiri terbimbing pada materi elastisitas. Soal posttest sama dengan soal pretest yaitu 25 soal pilihan ganda. Setelah nilai pretest dan posttest diperoleh, nilai tersebut dianalisis dan diperoleh hasil bahwa ada peningkatan hasil belajar, sikap disiplin belajar dan kreativitas siswa kelas X TKR 4.

Analisis data yang digunakan adalah hasil pretest dan posttest dan hasil observasi disiplin belajar dan kreativitas siswa yang diukur sebelum dan setelah menggunakan modul elastisitas berbasis inkuiri terbimbing pada kelas pengujian produk. Hasil pretest dan posttest serta hasil observasi disiplin belajar dan kreativitas siswa sebelum dan setelah menggunakan modul diuji Gain Score untuk mengetahui efektifitasnya.

Sedangkan analisis untuk mengetahui keefektifan dalam pembelajaran menggunakan gain score ternormalisasi untuk pretest dan posttest pengujian produk. Berdasarkan perhitungan gain score untuk kelas pengujian peningkatan hasil belajar termasuk kategori sedang. Peningkatan hasil belajar disebabkan tahapan inkuiri pada modul yang dapat membuat siswa aktif. Hal tersebut sesuai dengan pernyataan Jufri (2013:161) bahwa, tiap-tiap individu peserta didik memerlukan sarana pendukung belajar yang eksplisit dan panduan untuk memahami dan mengerjakan inkuiri ilmiah serta memahami tubuh ilmu pengetahuan. Bimbingan guru juga sangat berperan dalam meningkatkan hasil belajar siswa. Pada saat siswa menghadapi kesulitan dalam proses pembelajaran, guru membantu dan mengarahkan siswa dalam memecahkan masalah tersebut. Setelah mendapatkan bimbingan dan arahan dari guru maka siswa dapat menyelesaikan dan memecahkan masalah dan kesulitan yang dihadapi. Hal tersebut sesuai dengan pendapat Daryanto (2013:8) yang menyatakan bahwa, dalam pengembangan secara keseluruhan guru perlu mempertimbangkan tentang kemungkinan kesulitan belajar siswa sehingga modul yang disajikan pada prinsipnya diarahkan untuk membantu siswa memechkan masalah yang dihadapinya dalam belajar.

Peningkatan sikap disiplin belajar termasuk kategori tinggi, dan peningkatan kreativitas siswa sebelum dan setelah menggunakan modul elastisitas berbasis inkuiri terbimbing termasuk kategori sedang. Setelah dilakukan pembelajaran menggunakan modul elastisitas berbasis inkuiri terbimbing, seluruh siswa diberikan angket untuk mengetahui respon dari siswa. Angket uji skala besar yang diberikan kepada kelas X TKR 4 sama dengan angket yang diberikan pada siswa saat uji coba kecil. Hasil respon siswa diperoleh pada kategori baik.

Sikap disiplin belajar siswa juga meningkat karena dalam pembelajaran menggunakan modul berbasis inkuiri terbimbing tahapan dan langkah kerja sudah disediakan. Dalam pembelajaran guru juga memberikan bimbingan dan dorongan pada siswa untuk selalu mengumpulkan tugastugas yang tercantum pada modul dan selalu taat pada tata tertib pada pembelajaran fisika. Selain bimbingan dari guru dalam modul berbasis inkuiri terbimbing juga telah ditulis langkahlangkah dalam melaksanakan percobaan sehingga dalam percobaan mengikuti langkah-langkah tersebut. Pembelajaran yang dilaksanakan sesuai dengan pernyataan Tu'u dalam Budiman (2010) yang menyatakan bahwa disiplin sebagai upaya mengendalikan diri dan sikap mental individu atau masyarakat dalam mengembangkan kepatuhan dan ketaatan terhadap peraturan dan tata tertib berdasarkan dorongan dan kesadaran yang muncul dari dalam hatinya.

Peningkatan sikap disiplin belajar dan kreativitas siswa disebabkan pembelajaran yang dilaksanakan dengan modul menggunakan tahapan inkuiri terbimbing. Sehingga siswa dalam melaksanakan pembelajaran melalui tahap berorientasi, merumuskan masalah, merumuskan hipotesis, melakukan 
percobaan dan membuat kesimpulan. Dengan tahapan tersebut siswa terlibat secara aktif dan terlibat langsung dalam pembelajaran. Hal tersebut sesuai dengan pernyataan Torrance dalam Munandar (2012:27) bahwa kreativitas adalah proses merasakan dan mengamati adanya masalah, membuat dugaan tentang kekurangan masalah ini, menilai atau menguji dugaan atau hipotesis, kemudian mengubah dan mengujinya lagi, dan akhirnya menyampaikan hasil-hasilnya.

\section{Disseminate}

Pada tahap dissemination modul diberikan kepada 14 guru fisika SMK. Terdiri dari 5 dari SMK Negeri dan 4 SMK swasta. Semua guru memberikan komentar yang positif terhadap modul elastisitas berbasis inkuiri terbimbing. Skor rata-rata dari respon guru adalah 246,43. Skor maksimal respon guru terhadap modul adalah 310. Persentase rata-rata skor respon tersebut adalah 79,49 dan masuk dalam kategori baik. Kesimpulan dari respon guru, modul elastisitas berbasis inkuiri terbimbing adalah layak digunakan untuk pembelajaran fisika dengan rata-rata prosentase keidealan 79,49\%. Hal tersebut sesuai dengan pendapat Daryanto (2013:9) yang menyatakan bahwa, modul merupakan salah satu bentuk bahan ajar yang dikemas secara utuh dan sistematis, didalamnya memuat seperangkat pengalaman belajar yang terencana dan didesain untuk membantu peserta didik menguasai tujuan belajar yang spesifik. Pada tahap ini dapat diketahui juga bahwa modul menjadi pilihan alternatif bagi guru sebagai bahan belajar pendamping atau dapat juga dijadikan bahan belajar utama.

\section{Temuan Lapangan}

Temuan pada penelitian dan pengembangan modul elastisitas berbasis inkuiri terbimbing, yaitu: pembelajaran inkuiri sangat sesuai jika digunakan dalam pembelajaran yang berkaitan dengan kehidupan sehari-hari dan memiliki hubungan erat terhadap teknologi dan dunia SMK, Siswa mengalami pembelajaran secara langsung menggunakan modul, pembelajaran yang memberikan pengalaman langsung terhadap dunia nyata dapat memancing keaktifan siswa siswa untuk belajar, praktikum dilaksanakan di kelas dengan keterbatasan beberapa alat, pembagian kelompok secara heterogen dapat membantu siswa yang memiliki kemampuan yang rendah, Sikap disiplin belajar dan kreativitas harus dibelajarkan secara terus menerus dan berkesinambungan, Penilaian hasil belajar, sikap disiplin belajar dan kreativitas diperoleh dari soal pretest dan posttest sesuai dengan askpek dari variabel tersebut.

\section{Keterbatasan Penelitian}

Keterbatasan penelitian ini adalah: Modul elastisitas berbasis inkuiri terbimbing hanya dikembangkan pada satu bab materi, Penyebaran modul elastisitas berbasis inkuiri terbimbing sangat terbatas yaitu hanya pada beberapa guru di sekolah terdekat dan hanya pada 14 guru fisika, Penilaian hasil belajar, disiplin belajar dan kreativitas siswa hanya berdasarkan hasil dari pretest dan posttest, Peneliti masih menggunakan soal dengan kategori mudah untuk mengukur hasil belajar siswa, khususnya hasil belajar kognitif.

\section{Kesimpulan dan Rekomendasi}

\section{Kesimpulan}

Pengembangan modul fisika berbasis inkuiri terbimbing untuk meningkatkan disiplin belajar dan kreativitas siswa pada materi elastisitas adalah modul pembelajaran yang dikembangkan berdasarkan komponen pembelajaran berbasis inkuiri terbimbing. Pengembangan modul menggunakan model 4D meliputi define, design, development, and disseminate.

Modul dikategorikan layak karena telah melalui beberapa validasi dan uji kelayakan. Dimulai dari validasi dan uji kelayakan oleh validator materi, media, bahasa, teman sejawat dan guru fisika modul termasuk dalam kategori baik dan layak. Hal tersebut didukung dengan hasil perhitungan yang menunjukkan nilai rata- 
rata validasi 84 penilaian lebih besar dari nilai cut off sebesar 83. Modul mendapatkan respon dari siswa dan guru dalam proses pembelajaran yang dinilai dari angket respon mengategorikan modul baik.

Modul elastisitas berbasis inkuiri terbimbing efektif untuk meningkatkan hasil belajar, sikap disiplin belajar dan kreativitas siswa. Hal tersebut dapat dilihat dari hasil dari nilai gain ternormalisasi untuk nilai pretest dan post test hasil belajar siswa termasuk dalam kategori sedang dengan nilai gain 0,59 , sikap disiplin belajar siswa dengan nilai gain ternormalisasi sebesar 0,61 atau masuk dalam kategori peningkatan tinggi. Dapat dilihat juga peningkatan kreativitas siswa dari nilai gain ternormalisasi sebesar 0,51 atau masuk dalam kategori peningkatan sedang. Dari perhitungan diatas maka dapat disimpulkan bahwa modul berbasis inkuiri terbimbing efektif untuk meningkatkan disiplin belajar dan kreativitas siswa dalam pembelajaran fisika.

\section{Rekomendasi}

Metode pembelajaran di kelas hendaknya lebih variatif serta guru sebaiknya memahami karakteristik model pembelajaran yang cocok dan yang akan diterapkan di kelas. Guru hendaknya mulai mengembangkan modul pembelajaran fisika yang sesuai dengan karakteristik materi yang akan diberikan sehingga siswa dapat menerima materi tersebut dengan baik. Pengembangan modul ini bisa digunakan untuk implementasi kurikulum 2013 karena modul berbasis inkuiri terbimbing yang setiap tahapan pembelajarannya sangat sesuai dengan pendekatan saintifik.

Keterbatasan penelitian ini dapat digunakan sebagai acuan untuk mengembangkan penelitian sejenis, terutama penelitian pengembangan modul dalam pembelajaran fisika. Peneliti juga dapat mengembangkan modul dengan karakteristik model pembelajaran dan materi yang berbeda sehingga menambah variasi bahan pembelajaran.

\section{Daftar Pustaka}

Azwar. S. (2007). Penyusunan Skala. Yogyakarta: Pustaka Belajar

Budiman. (2010). Angket Disiplin Belajar. http://chemistrybudiman07. Blogspot .com/2010/03/angket-kedisiplinansiswa.html

Daryanto. (2013). Menyusun Modul. Yogyakarta: Gava Media

Depdiknas. (2008). Teknik Penyusunan Modul. Jakarta : Direktorat Jenderal Manajemen Pendidikan Dasar dan Menengah, Departemen Pendidikan Nasional.

Gunawan. A. (2008). Genius Learning Strategi. Jakarta: Pustaka Utama.

Hamdani. (2010). Strategi Belajar Mengajar. Bandung: Pustaka Setia

Jufri, W. (2013). Belajar dan Pembelajaran Sains. Bandung: Pustaka Reka Cipta

Meltzer. D.E. (2002). The Relationship between Mathematics Preparation and Conceptual Learning Gains in Physics: a Possible "Hidden Variable"in Diagnostic Pretest Scores. Department of Physics a and Astronomy, Lowa State University, Ames, Lowa 50011.Am. J. Phys. Vol 70, No. 12, Hlm 1259-1268

Munandar, U. (2012). Pengembangan Kreativitas Anak Berbakat. Jakarta: Rineka Cipta

Depdiknas. (2013). Peraturan Menteri Pendidikan dan Kebudayaan Nomor 70 Tahun 2013 tentang Kurikulum SMA. Jakarta: Diknas

Prastowo, A. (2011). Panduan Kreatif Membuat Bahan Ajar Inovatif. Yogyakarta: Diva Press.

Purwanto. (2007). Pengembangan Modul. Jakarta: PUSTEKKOM Depdiknas

Putra, S.R. (2013). Desain Belajar Mengajar Kreatif Berbasis Sains. Jogjakarta: Divapress

Sungkono. (2003). Pengembangan Bahan Ajar. Yogyakarta: FIP UNY. 
Sanjaya, W. (2013). Strategi Pembelajaran Berorientasi standar Proses Pendidikan. Jakarta: Kencana Prenada Media Goup.

Suparno, P. (2013). Filsafat konstruksivisme dan pendidikan. Yogyakarta: Kanisius.

Thiagarajan, S. et al. (1974). Instructional Development For Training Teachers of Exeptional Children. Minesota: Indiana University.

Trianto. (2008). Mendesain Pembelajaran Kontekstual (Contextual Teaching and Learning) di kelas. Jakarta, Cerdas Pustaka

Winnie. S. (2009). Pendekatan Kombinasi Metode AHP dan Metode Cut Off Point pada Tahap Analisis Keputusan Perancangan Sistem Informasi Penjualan

PT.X.http://eprints.undip.ac.id. Diakses 10

Mei

2015. 